\title{
Simultaneous extraction of soil phytoavailable cadmium, copper, and lead by chelating resin membrane
}

\author{
Dar-Yuan Lee and Hsiu-Ching Zheng \\ Graduate Institute of Agricultural Chemistry, National Taiwan University, Taipei, Taiwan, Republic of China
}

Received 14 December 1993. Accepted in revised form 12 April 1994

Key words: contaminated soils, heavy metal, ion exchange resin, plant uptake

\begin{abstract}
Cadmium, copper, and lead were extracted from suspensions of contaminated soils using metal chelating exchange resin membranes. Nine soils with widely varying properties and $\mathrm{Cd}, \mathrm{Cu}$ and $\mathrm{Pb}$ levels were tested. Soil suspensions made up with $4 \mathrm{~g}$ in $40 \mathrm{~mL}$ deionized water were equilibrated with $5 \mathrm{~cm}^{2}$ Ca-saturated Chelex exchange resin membrane which was retained inside a polypropylene bag and shaken at $150 \mathrm{rpm}$ for $24 \mathrm{hrs}$. Resin membrane extractable $\mathrm{Cd}, \mathrm{Cu}$ and $\mathrm{Pb}$ of the soils were correlated with $\mathrm{Cd}, \mathrm{Cu}$, and $\mathrm{Pb}$ uptake by young wheat seedlings grown in these soils and compared with soil $\mathrm{Cd}, \mathrm{Cu}$, and $\mathrm{Pb}$ extracted by $0.1 \mathrm{M} \mathrm{HCl}, 0.01 M \mathrm{CaCl}_{2}$, and $0.005 \mathrm{M}$ Diethylenetriamine pentaacetic acid (DTPA). The amounts of $\mathrm{Cd}, \mathrm{Cu}$ and $\mathrm{Pb}$ extracted by the $\mathrm{Ca}$-saturated $\mathrm{Chelex}$ membrane from all tested soils correlated well with those absorbed by young wheat seedlings. The Ca-saturated Chelex membrane extractable $\mathrm{Cd}, \mathrm{Cu}$ and $\mathrm{Pb}$ of the soil had the strongest correlation with plant uptake $\mathrm{Cd}, \mathrm{Cu}$ and $\mathrm{Pb}$ among the extraction methods we tested. It was demonstrated that the Ca-saturated Chelex membrane extraction is an appropriate method in simultaneously estimating $\mathrm{Cd}, \mathrm{Cu}$ and $\mathrm{Pb}$ phytoavailability of soil and is applicable to a wide range of soils.
\end{abstract}

\section{Introduction}

Several soil diagnostic tests using chemical extractants have been proposed to estimate the phytoavailability of $\mathrm{Cd}, \mathrm{Cu}$, and $\mathrm{Pb}$ (Baker and Amacher, 1982; Risser and Baker, 1990). Phytoavailability, in this case, refers to availability of soil-borne metals to plant absorption and is customarily measured as amounts of metals absorbed by plants grown under optimal growing conditions. These methods were successful in estimating the phytoavailability of $\mathrm{Cd}, \mathrm{Cu}$ and $\mathrm{Pb}$ in soils under limited conditions. But none of the methods has been able to predict consistently the phytoavailability of metal for soils of various physical and chemical properties.

Another approach to estimating metal phytoavailability of soil is to introduce a strong or infinite sink for soil metals. The infinite sink method is chemically less destructive to the soil and its reaction with the soil resembles the way plants extract elements from the soil. The ion exchange resins have been used as infinite sinks in extracting available elements from soils (Amer et al., 1955; Sibbesen, 1977; Skogley et al., 1990). A chelating exchange resin is superior to an ion exchange resin in which trace metals must compete with much higher concentrations of metals such as $\mathrm{Ca}, \mathrm{Mg}$, and K. Jing and Logan (1991 and 1992) used chelating resin beads as infinite sinks in extracting plant available Cd from sewage sludges. Lee and Zheng (1993) reported a chelating resin membrane method for estimation of phytoavailability of $\mathrm{Cd}$ in the soil. Their results showed that $\mathrm{Cd}$ uptake by wheat seedlings has a stronger correlation with extractable $\mathrm{Cd}$ by the chelating resin membrane than with soil Cd extracted by four conventional chemical extraction methods for a variety of soils. In this study, the chelating resin membrane method to estimate phytoavailable soil metals was further evaluated with simultaneous extraction of $\mathrm{Cd}, \mathrm{Cu}$, and $\mathrm{Pb}$ of soils which had different physical and chemical properties and contained varying amounts of $\mathrm{Cd}$, $\mathrm{Cu}$, and $\mathrm{Pb}$. Amounts extracted were correlated with $\mathrm{Cd}, \mathrm{Cu}$, and $\mathrm{Pb}$ absorption by wheat seedlings grown 
on the same soils. The results were also compared with the amounts of $\mathrm{Cd}, \mathrm{Cu}$, and $\mathrm{Pb}$ extracted using other chemical extraction methods.

\section{Materials and methods}

\section{Preparation of resin membrane}

Sheets of Na-saturated chelating resin membrane (Chelex 12" $\times 12^{\prime \prime}$ membrane sheets, Bio-Rex ion exchange membrane sheets, Bio-Rad) were cut into $1 \mathrm{~cm} \times 5 \mathrm{~cm}$ pieces. The $\mathrm{Na}$-form of resin membrane was transformed into Ca-saturated form for use. The details of preparing the resin membrane, including transformation to Ca-form and regeneration of spentmembrane, were described by Lee and Zheng (1993).

Cadmium, $\mathrm{Cu}$, and $\mathrm{Pb}$ adsorption by chelating resin membrane from metal solution mixture

A series of 50-mL centrifuge tubes each with one piece of the resin membrane $\left(5 \mathrm{~cm}^{2}\right)$ enclosed in a polypropylene (PP) mesh bag ( 60 mesh) were filled with $40 \mathrm{~mL}$ of solution containing $2 \mathrm{mg} \mathrm{L}^{-1} \mathrm{Cd}, 20 \mathrm{mg} \mathrm{L}^{-1} \mathrm{Cu}$, and $24 \mathrm{mg} \mathrm{L}^{-1} \mathrm{~Pb}$. The tubes were then shaken at 150 rpm and $25^{\circ} \mathrm{C}$ for periods ranging from 2 to $30 \mathrm{hrs}$. At the end of shaking periods, the resin membranes along with the bags were recovered, rinsed thoroughly with deionized water, and air-dried. The membranes were then placed into a set of 50-mL centrifuge tubes containing $40 \mathrm{~mL}$ aliquots of $1 \mathrm{M} \mathrm{HCl}$ and the tubes shaken for $24 \mathrm{hrs}$ to remove the $\mathrm{Cd}, \mathrm{Cu}$, and $\mathrm{Pb}$ adsorbed on the membrane. The desorption process was repeated once. Cadmium, $\mathrm{Cu}$, and $\mathrm{Pb}$ in the solutions was determined by atomic absorption spectroscopy.

\section{Extraction of soil-borne $\mathrm{Cd}, \mathrm{Cu}$, and $\mathrm{Pb}$ by resin mem- brane}

Four-gram of soil (passed through 80 mesh), $40 \mathrm{~mL}$ of deionized water, and one piece of Ca-saturated Chelex resin membrane $\left(5 \mathrm{~cm}^{2}\right)$ in a PP bag were placed in a $50-\mathrm{mL}$ centrifuge tube. The tubes were shaken for $24 \mathrm{hrs}$. The soil suspensions were decanted and the resin membrane was recovered, rinsed thoroughly with distilled water, and air-dried. It was then transferred into a clean $50-\mathrm{mL}$ centrifuge tube and $40-\mathrm{mL}$ aliquots of $1 \mathrm{M} \mathrm{HCl}$ were added. The tube was shaken for 24 hrs to remove the $\mathrm{Cd}, \mathrm{Cu}$, and $\mathrm{Pb}$ adsorbed on the membrane. The $\mathrm{Cd}, \mathrm{Cu}$, and $\mathrm{Pb}$ desorption procedures were repeated once. The $\mathrm{Cd}, \mathrm{Cu}$, and $\mathrm{Pb}$ concentrations in the aliquots of $1 \mathrm{M} \mathrm{HCl}$ were determined by atomic absorption spectroscopy.

Cadmium, $\mathrm{Cu}$, and $\mathrm{Pb}$ uptake by young seedlings of wheat

A modified Neubauer method (Lee, 1983) was used to determine plant-extractable $\mathrm{Cd}, \mathrm{Cu}$, and $\mathrm{Pb}$ of the soil. Fifty-five wheat seeds (Triticum vulgare, variety Taichung select No. 2) were placed evenly in a series of plastic bottles which were filled with the soil and acidwashed silica sand. The details of wheat cultivation were described by Lee and Zheng (1993). Each experimental treatment was triplicated. The experiment was carried out in a greenhouse at $26 \pm 10^{\circ} \mathrm{C}$ for 30 days. At the end of the experiment, seedlings including roots were washed free of silica sand and soil, oven-dried at $70-80^{\circ} \mathrm{C}$ for $48 \mathrm{hrs}$, ground to pass a 60 -mesh sieve, and stored for analysis.

\section{Extractable soil $\mathrm{Cd}, \mathrm{Cu}$, and $\mathrm{Pb}$ by other methods}

The $\mathrm{Cd}, \mathrm{Cu}$, and $\mathrm{Pb}$ in soils were also extracted by $0.1 M \mathrm{HCl}$ (Nelson et al., 1959), $0.01 M \mathrm{CaCl}_{2}$ (Whitten and Ritchie, 1991), DTPA (pH=7.3) (Lindsay and Norvell, 1978), and DTPA(pH=5.3) (Norvell, 1984) and the concentration of $\mathrm{Cd}, \mathrm{Cu}$, and $\mathrm{Pb}$ in the extracts were determined by atomic absorption spectroscopy.

\section{Soil treatments}

Four soils used in this study were selected from agricultural lands in Taiwan which were contaminated primarily due to irrigation with $\mathrm{Cd}, \mathrm{Cu}$, or $\mathrm{Pb}$ containing waste water discharged from chemical plants (Lee and Liao, 1990). Five uncontaminated soils which represented soils of the major agricultural areas in Taiwan were also used. The properties of these soils were summarized in Table 1 . The soils varied widely in $\mathrm{pH}$, texture, and CEC. To test the method's applicability to major soils of Taiwan, the four uncontaminated soils were treated with various levels of $\mathrm{Cd}, \mathrm{Cu}$, and $\mathrm{Pb}$. The amounts of heavy metal addition for various treatments are shown in Table 2. Cadmium, $\mathrm{Cu}$, and $\mathrm{Pb}$ were added as $\mathrm{CdCl}_{2} .2 .5 \mathrm{H}_{2} \mathrm{O}, \mathrm{CuCl}_{2} .2 \mathrm{H}_{2} \mathrm{O}$, and $\mathrm{Pb}\left(\mathrm{NO}_{3}\right)_{2}$ solutions. The chemical forms of these metals were similar to those presented in industrial waste water in Taiwan. The treated soils underwent 3 wettingdrying cycles at room temperature. Following these treatments, the soils were ground, passed through a 
Table 1. Physical and chemical properties of the soils studied

\begin{tabular}{|c|c|c|c|c|c|c|c|}
\hline Soil series ${ }^{a}$ & Classification & $\begin{array}{c}\mathrm{pH} \\
\mathrm{H}_{2} \mathrm{O}\end{array}$ & $\begin{array}{c}\text { Organic } \\
\text { matter } \\
(\%)\end{array}$ & $\begin{array}{c}\mathrm{CEC} \\
\left(\mathrm{cmol}(+) \mathrm{kg}^{-1}\right)\end{array}$ & Texture & $\begin{array}{c}\text { Free } \\
\mathrm{Fe}_{2} \mathrm{O}_{3} \\
(\%)\end{array}$ & $\begin{array}{c}\text { Free } \\
\mathrm{Al}_{2} \mathrm{O}_{3} \\
(\%)\end{array}$ \\
\hline Pinchen $(\mathrm{Pc})$ & $\begin{array}{l}\text { Tropeptic } \\
\text { Haplorthox }\end{array}$ & 4.0 & 2.0 & 8.4 & $\mathrm{SiC}$ & 2.40 & 0.38 \\
\hline Jente (Je) & Haplaquept & 5.3 & 2.2 & 6.4 & $\mathrm{~L}$ & 0.63 & 0.09 \\
\hline Erhlin (Eh) & Haplaquept & 6.5 & 2.6 & 9.1 & $\mathrm{SiCL}$ & 0.60 & 0.07 \\
\hline Chengchung (Cf) & Udifluvent & 7.7 & 1.5 & 6.0 & $\mathrm{~L}$ & 0.55 & 0.06 \\
\hline Taikang (Tk) & $\begin{array}{l}\text { Fluventic } \\
\text { Ustochrept }\end{array}$ & 8.2 & 1.5 & 16.3 & $\mathrm{C}$ & 1.57 & 0.11 \\
\hline Chunghsing $(\mathrm{Ce})^{b}$ & $\begin{array}{l}\text { Typic } \\
\text { Paleudult }\end{array}$ & 4.9 & 1.4 & 8.8 & $\mathrm{SiC}$ & 0.06 & 0.23 \\
\hline Tsaota $(\mathrm{Ts})^{b}$ & $\begin{array}{l}\text { Typic } \\
\text { Quartzipsamment }\end{array}$ & 5.2 & 1.0 & 4.2 & SL & 0.47 & 0.10 \\
\hline Annei $(A n)^{b}$ & Udifluvent & 7.4 & 1.0 & 5.1 & SL & 0.74 & 0.11 \\
\hline Neuniaokang $(\mathrm{YNn})^{\mathbf{b}}$ & Udifluvent & 7.7 & 5.4 & 8.3 & $\mathrm{~L}$ & 0.74 & 0.11 \\
\hline
\end{tabular}

${ }^{\mathrm{a}}$ The letters in the parentheses represent the abbreviation of soil name.

${ }^{b}$ Collected from contaminated agricultural soils.

Table 2. The amounts of heavy metal added into uncontaminated soils for various levels of treatments

\begin{tabular}{lrrr}
\hline \multirow{2}{*}{$\begin{array}{l}\text { Treatment } \\
\text { level }\end{array}$} & \multicolumn{3}{c}{ Amounts of metal added $\left(\mathrm{mg} \mathrm{kg}^{-1}\right)$} \\
\cline { 2 - 4 } & $\mathrm{Cd}$ & $\mathrm{Cu}$ & $\mathrm{Pb}$ \\
\hline 0 & 0 & 0 & 0 \\
1 & 5 & 50 & 60 \\
2 & 10 & 100 & 120 \\
3 & 20 & 200 & 240 \\
\hline
\end{tabular}

40-mesh sieve, mixed thoroughly, and stored for plant uptake experiments.

\section{Results and discussion}

\section{Extraction conditions}

The Ca-saturated Chelex membrane is effective in adsorbing $\mathrm{Cd}, \mathrm{Cu}$, and $\mathrm{Pb}$ from the solutions containing a mixture of metals and the adsorbed $\mathrm{Cd}, \mathrm{Cu}$, and $\mathrm{Pb}$ can also be effectively removed from the membrane by $1 \mathrm{M} \mathrm{HCl}$. The recoveries of $\mathrm{Cd}, \mathrm{Cu}$, and $\mathrm{Pb}$ by the $\mathrm{Ca}$-Chelex membranes reached 93,100 , and $100 \%$, respectively with $20 \mathrm{hrs}$ of equilibration (Fig. 1). The

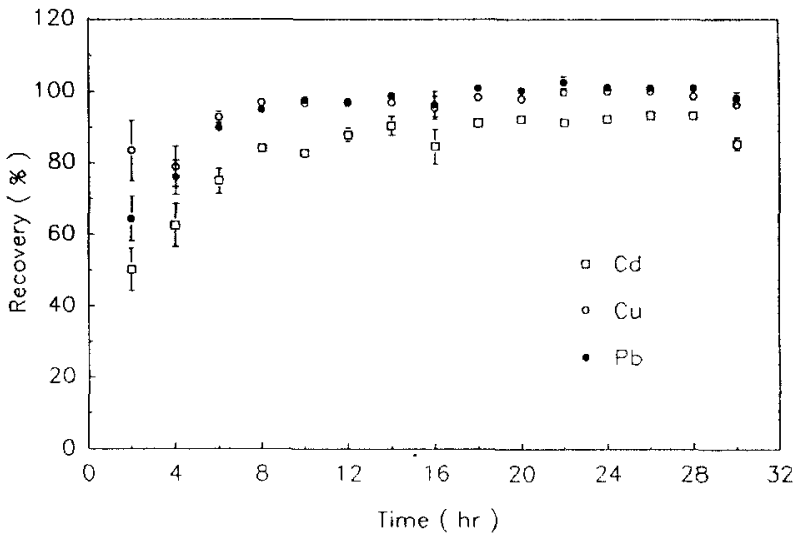

Fig. 1. The recovery of $\mathrm{Cd}, \mathrm{Cu}$, and $\mathrm{Pb}$ for $5 \mathrm{~cm}^{2}$ Ca-saturated Chelex resin membrane in $40 \mathrm{~mL}$ solution $\left(\mathrm{Cd} 2 \mathrm{mg} \mathrm{L}^{-1}, \mathrm{Cu} 20 \mathrm{mg}\right.$ $\mathrm{L}^{-1}$, and $\mathrm{Pb} 24 \mathrm{mg} \mathrm{L}^{-1}$ ) as a function of time. (The error bar stands for $\pm 1 \mathrm{SD}$.)

high recovery rates by the Ca-saturated Chelex membrane for $\mathrm{Cd}, \mathrm{Cu}$, and $\mathrm{Pb}$ make the membrane suitable for extracting these three metals simultaneously. The extraction time was set at $24 \mathrm{hrs}$ for all the experiments, as 20 hrs were sufficient for the $\mathrm{Cd}, \mathrm{Cu}$, and $\mathrm{Pb}$ adsorption to reach equilibrium. The cation exchange capacity of Ca-saturated Chelex membrane for divalent metal is above $8 \mu \mathrm{mol} \mathrm{cm}^{-2}$ (Lee and Zheng, 1993). Five $\mathrm{cm}^{2}$ of Ca-saturated Chelex membrane will pro- 
Table 3. Dry matter weight and concentration of $\mathrm{Cd}, \mathrm{Pb}, \mathrm{Cu}$ in wheat seedlings grown in all tested soils with various treatments

\begin{tabular}{|c|c|c|c|c|}
\hline \multirow{2}{*}{ Soil $^{\mathrm{a}}$} & \multirow{2}{*}{$\begin{array}{c}\text { Dry matter } \\
\text { weight } \\
\text { (g/pot) }\end{array}$} & \multicolumn{3}{|c|}{ Concentration $\left(\mathrm{mg} \mathrm{kg}^{-1}\right)$} \\
\hline & & $\mathrm{Cd}$ & $\mathrm{Cu}$ & $\mathrm{Pb}$ \\
\hline $\mathrm{Pc}^{\mathrm{b}}$ & $1.91 \pm 0.04$ & $\mathrm{ND}^{\mathrm{c}}$ & $50 \pm 10$ & $9 \pm 8$ \\
\hline Pcl & $2.1 \pm 0.3$ & $18 \pm 1$ & $150 \pm 70$ & $5 \pm 1$ \\
\hline Pc2 & $2.1 \pm 0.3$ & $54 \pm 5$ & $230 \pm 20$ & $20 \pm 10$ \\
\hline $\mathrm{Pc} 3$ & $1.9 \pm 0.1$ & $180 \pm 10$ & $470 \pm 40$ & $60 \pm 10$ \\
\hline $\mathrm{Je} 0$ & $2.3 \pm 0.1$ & $\mathrm{ND}^{\mathrm{c}}$ & $60 \pm 20$ & $21 \pm 5$ \\
\hline Jel & $2.3 \pm 0.1$ & $13 \pm 1$ & $80 \pm 20$ & $23 \pm 7$ \\
\hline Je2 & $2.7 \pm 0.3$ & $29 \pm 4$ & $220 \pm 70$ & $26 \pm 5$ \\
\hline Je3 & $3.0 \pm 0.3$ & $64 \pm 7$ & $410 \pm 70$ & $23 \pm 6$ \\
\hline Eho & $2.4 \pm 0.2$ & $\mathrm{ND}^{\mathrm{c}}$ & $40 \pm 10$ & $15 \pm 6$ \\
\hline Eh1 & $2.4 \pm 0.1$ & $17 \pm 3$ & $46 \pm 5$ & $17 \pm 4$ \\
\hline Eh2 & $2.4 \pm 0.2$ & $29 \pm 3$ & $80 \pm 10$ & $23 \pm 3$ \\
\hline Eh3 & $2.5 \pm 0.1$ & $28 \pm 1$ & $110 \pm 30$ & $28 \pm 6$ \\
\hline Cf0 & $2.5 \pm 0.2$ & $\mathrm{ND}^{c}$ & $70 \pm 20$ & $9 \pm 5$ \\
\hline Cf1 & $2.5 \pm 0.1$ & $7 \pm 1$ & $76 \pm 3$ & $15 \pm 8$ \\
\hline Cf2 & $2.58 \pm 0.07$ & $14 \pm 1$ & $100 \pm 20$ & $17 \pm 5$ \\
\hline Cf3 & $2.52 \pm 0.06$ & $30 \pm 3$ & $160 \pm 10$ & $28 \pm 7$ \\
\hline Tk0 & $1.8 \pm 0.2$ & $N^{c}$ & $70 \pm 10$ & $12 \pm 2$ \\
\hline Tkl & $1.88 \pm 0.08$ & $8 \pm 1$ & $60 \pm 10$ & $10 \pm 7$ \\
\hline Tk2 & $1.99 \pm 0.03$ & $15 \pm 1$ & $80 \pm 10$ & $13 \pm 5$ \\
\hline Tk3 & $1.90 \pm 0.03$ & $23 \pm 1$ & $110 \pm 10$ & $22 \pm 6$ \\
\hline $\mathrm{Ce}$ & $2.2 \pm 0.1$ & $65 \pm 2$ & $35 \pm 4$ & $10 \pm 10$ \\
\hline Ts & $2.3 \pm 0.1$ & $30 \pm 3$ & $35 \pm 2$ & $23 \pm 8$ \\
\hline An & $2.3 \pm 0.2$ & $N^{\mathfrak{C}}$ & $120 \pm 10$ & $4 \pm 1$ \\
\hline YNn & $2.1 \pm 0.1$ & $160 \pm 20$ & $90 \pm 40$ & $280 \pm 10$ \\
\hline
\end{tabular}

a The number following the abbreviation of soil name is the level of heavy metal added.

${ }^{b}$ For amount of heavy metal added see Table 2.

c < Detection limit $\left(0.05 \mathrm{mg} \mathrm{kg}^{-1}\right)$

vide exchange sites for at least $40 \mu \mathrm{mol}$ divalent metal which is sufficient for $\mathrm{Cd}, \mathrm{Cu}$, and $\mathrm{Pb}$ released from 4 $\mathrm{g}$ of heavily heavy metal-contaminated soils.

\section{Plant uptake of $\mathrm{Cd}, \mathrm{Cu}$, and $\mathrm{Pb}$}

The dry matter yields and $\mathrm{Cd}, \mathrm{Cu}$, and $\mathrm{Pb}$ concentrations of wheat seedlings grown in soils with various treatments are presented in Table 3 . The dry matter yields are not significantly different (at $p<0.05$ ) between the treatments. The growth of wheat seedlings was not inhibited by the $\mathrm{Cd}, \mathrm{Cu}$, and $\mathrm{Pb}$ in the soils, thus the total uptake of $\mathrm{Cd}, \mathrm{Cu}$, and $\mathrm{Pb}$ by wheat seedlings could be used to represent phytoavailability of $\mathrm{Cd}, \mathrm{Cu}$, and $\mathrm{Pb}$ in the soils.
Table 4. Correlation coefficients between $\mathrm{Cd}, \mathrm{Cu}$, and $\mathrm{Pb}$ uptake by wheat and those extracted by various methods

\begin{tabular}{lcll}
\hline Extraction method & $\mathrm{Cd}$ & $\mathrm{Cu}$ & $\mathrm{Pb}$ \\
\hline $0.1 \mathrm{M} \mathrm{HCl}$ & $0.61^{* *}$ & $0.60^{* *}$ & $0.98^{* * *}$ \\
$0.01 \mathrm{M} \mathrm{CaCl}$ & $0.93^{* * *}$ & $0.69^{* * *}$ & 0.06 \\
DTPA (pH 7.3) & $0.64^{* * *}$ & $0.71^{* * *}$ & $0.98^{* * *}$ \\
DTPA (pH 5.3) & $0.63^{* * *}$ & $0.52^{* *}$ & $0.99^{* * *}$ \\
Chelex resin membrane & $0.86^{* * *}$ & $0.82^{* * *}$ & $0.80^{* * *}$ \\
\hline
\end{tabular}

*** Significant at $0.1 \%$ level

** Significant at $1 \%$ level

Extractable soil $\mathrm{Cd}$ by resin membrane +vs. other methods

The correlations between $\mathrm{Cd}$ uptake by wheat seedlings and amounts of $\mathrm{Cd}$ extracted by all of the extraction methods were significant at $p<0.01$ (Table 4). The correlation coefficients were all larger than 0.61 . However, the strongest correlation of Cd uptake was with $0.01 \mathrm{M} \mathrm{CaCl}_{2}$ extracted soil $\mathrm{Cd}(\mathrm{r}=0.93)$, and the next highest was with resin membrane extracted Cd $(r=0.86)$. Resin membrane extractable-soil Cd, according to the correlation coefficients, was a better indicator of plant available $\mathrm{Cd}$ than $\mathrm{Cd}$ extracted by DTPA ( $r=0.64)$ and $0.1 \mathrm{M} \mathrm{HCl}(\mathrm{r}=0.61)$ extraction methods.

Extractable soil $\mathrm{Cu}$ by resin membrane vs. other methods

The correlations between $\mathrm{Cu}$ uptake by wheat seedlings and $\mathrm{Cu}$ extracted by all of the extraction methods we tested were significant at $p<0.01$ (Table 4). Resin membrane extractable-soil $\mathrm{Cu}$ however had the strongest correlation with plant uptake $\mathrm{Cu}(\mathrm{r}=0.82)$ and therefore, according to the correlation coefficients, was a better indicator of plant available $\mathrm{Cu}$ than $\mathrm{Cu}$ extracted by the other extraction methods $(r=0.52-$ 0.71 ) we tested.

Extractable soil $P b$ by resin membrane vs. other methods

The correlations between $\mathrm{Pb}$ uptake by wheat seedlings and $\mathrm{Pb}$ extracted by all of the tested extraction methods we tested ( $\mathrm{r}=0.80-0.99$ ) except the $0.01 \mathrm{M} \mathrm{CaCl}_{2}$ extraction method $(\mathrm{r}=0.06)$ were significant at $p<0.01$ (Table 4). 
When the phytoavailability of $\mathrm{Cd}, \mathrm{Cu}$, and $\mathrm{Pb}$ in the soil were considered separately using the extraction methods we tested, only the plant uptake of $\mathrm{Cu}$ was better correlated statistically with $\mathrm{Cu}$ extracted by the Chelex resin membrane than with $\mathrm{Cu}$ extracted by other diagnostic methods. However, when the phytoavailability of $\mathrm{Cd}, \mathrm{Cu}$, and $\mathrm{Pb}$ of soil were evaluated collectively, the $\mathrm{Cd}, \mathrm{Cu}$ and $\mathrm{Pb}$ extracted by the resin membrane were overall better indices of plant available $\mathrm{Cd}, \mathrm{Cu}$, and $\mathrm{Pb}$ than those extracted by other extraction methods we tested (Table 4). In addition, the resin membrane might be regenerated and used repeatedly. The membranes after metal extraction might be easily stored for later analysis or sent to centralized locations for metal determination, if necessary. In view of these advantages, the chelating resin membrane method is well suited to evaluate the quantities of plant-available $\mathrm{Cd}, \mathrm{Cu}$ and $\mathrm{Pb}$ in soils.

\section{Acknowledgements}

This research was sponsored in part by the Environmental Protection Administration, Republic of China, under grant No. EPA-82-E3H1-09-01. Special acknowledgement is due Dr Z S Chen, Department of Agricultural Chemistry, National Taiwan University, for his assistance and valuable discussions. The authors are grateful to Dr A C Chang, Department of Soil and Environmental Sciences, University of California, Riverside, for the helpful technical review of the manuscript.

\section{References}

Amer F, Bouldin D R, Black C A and Duke FR 1955 Characterization of soil phosphorus by anion exchange resin adsorption and P-32 equilibration. Plant and Soil 6,391-408.
Baker D E and Amacher M C 1982 Nickel, copper, zinc, and cadmium. In Methods of soil Analysis: II. Chemical and Microbiological Properties, 2nd ed., Eds. A L Page et al. pp 323-336. Soil Sci. Soc. Am., Madison, WI., USA.

Jing $J$ and Logan T J 1991 Chelating resin method for estimation of sludge cadmium bioavailability. Commun. Soil Sci. Plant Anal. $22,2029-2035$.

Jing J and Logan T J 1992 Effects of sewage sludge cadmium concentration on chemical extractability and plant uptake. J. Environ. Qual. 21, 73-81.

Lee D Y and Zheng H C 1993 Chelating resin membrane method for estimation of soil cadmium phytoavailability. Commun. Soil Sci. Plant Anal. 24, 685-700.

Lee F Y and Liao C R 1990 The forms, properties, and distribution of cadmium and lead in contaminated soils (1) Basic properties of soils and chemical analysis. J. Chinese Agric. Chem. Soc. 28, 378-386.

Lee T T 1983 The accumulation, transformation, and utilization of phosphorus fertilizer applied in different soils under upland condition. J. Agric. Res. China 32, 72-184.

Lindsay W L and Norvell W A 1978 Development of a DTPA test for zinc, iron, manganese and copper. Soil Sci. Soc. Am. J. 42, $421-428$.

Nelson JL, Boawn L C and Viets F G Jr 1959 A method for assessing zinc status of soils using acid-extractable zinc and 'titractable alkalinity' values. Soil Sci. 88, 275-283.

Norvell W A 1984 Comparison of chelating agents as extractants for metals in diverse soil materials. Soil Sci. Soc. Am. J. 48, 1285-1292.

Risser J A and Baker D E 1990. Testing soils for toxic metals. In Soil Testing and Plant Analysis, 3rd ed. Ed. R L Westerman. pp 275-298. Soil Sci. Soc. Am., Madison, WI, U S A.

Sibbesen E 1977. A simple ion-exchange resin procedure for extracting plant-available elements from soil. Plant and Soil 46, 665669.

Skogley E O, Georgitis S J, Yang J E and Schaff B E 1990 The phytoavailability soil test - PST. Commun. Soil Sci. Plant Anal. 21, 1229-1243.

Whitten M G and Ritchie G S P 1991 Calcium chloride extractable cadmium as an estimate of cadmium uptake by subterranean clover. Aust. J. Soil Res. 29, 215-221.

Section editor: A C Borstlap 